\title{
Palestinian State through the Official and Unofficial Israeli Perspective
}

\author{
Rami Saleh Abdelrazeq Musleh ${ }^{1}$, Mahmoud Ismail ${ }^{1} \&$ Dala Mahmoud ${ }^{1}$ \\ ${ }^{1}$ Faculty of Economics and Political Science, Cairo University, Cairo, Egypt \\ Correspondence: Rami Saleh Adbelrazeq Musleh. E-mail: ramimusleh842@gmail.com
}

Received: December 26, 2017

doi:10.5539/ass.v14n3p55

\author{
Accepted: December 28, 2017 \\ Online Published: February 26, 2018 \\ URL: https://doi.org/10.5539/ass.v14n3p55
}

\begin{abstract}
The study focused on the Palestinian state as depicted in the Israeli political discourse. It showed that the Israeli strategy is based on denying the establishment of a Palestinian state alongside the Israeli one. Israel's main concern is to protect its national security at all costs. The study showed the Israeli political factions' opposition to the formation of an independent Palestinian state in addition to their refusal to give up certain parts of the West Bank due to religious and geopolitical reasons. To discuss this topic and achieve the required results, the analytical descriptive approach is adopted by the researcher. The study concluded that the Israeli leadership and its projects to solve the Palestinian issue do not amount to the establishment of a Palestinian state. This leadership simply aims to impress the international public opinion that Israel wants peace. In contrast, the Israeli public has shown that it cannot accept a Palestinian state, and the public opinion of the Palestinian state is not different from that of the political parties and leaders in Israel.
\end{abstract}

Keywords: Palestinian State, settlement, Israeli Political Parties, Israeli National Security

\section{Introduction}

The idea of the Palestinian state went through several stages. The stage where Palestine was divided and Israel was established was not a spur of the moment thing. It was a stage with historical dimensions that first started with the declaration made by Arthur Belfour, British foreign affairs minister, in 1917. The United Kingdom transferred the file to the United Nations, which was influenced by the influence of the major powers. This resulted in Resolution 181 of the General Assembly of the United Nations on November 29, 1947, dividing Palestine into Jewish and Arab states.

Israel has occupied the part of the land given to it by the UN resolution and more than half of the area allocated to the Arab state. This made all the actions based on this decision illegal because Israel refused to recognize the establishment of an Arab state in Palestine. This refusal arose from the fear of the demographic threat and security for the Israeli population. The Palestinian Israeli negotiations began and were culminated in the Oslo Accords on the Palestinian willingness to recognize the State of Israel on the basis of UN Security Council Resolutions 242 and 338. The Declaration of Principles was reached on $13^{\text {th }}$ September 1993. However, the core issues of borders, refugees, Jerusalem and settlements were not resolved.

The conflict between Palestinians and Israelis have escalated after the outbreak of the Al-Aqsa Intifada in 2000, following which the negotiations between the two sides ended and the situation returned to what it was. The United States began to find a way to resolve the conflict, which was announced by President George W. Bush on June 24, 2002, American settlement in the Middle East, which included the establishment of a Palestinian state alongside Israel, did not address the vision of prejudice to some of the Palestinian constants, but after about two decades the parties were unable to reach a settlement leading to the declaration of a Palestinian state alongside the State of Israel. Israel has seen that the idea of establishing a Palestinian state is not a realistic option to achieve its security and stability.

\section{Israeli Policy towards the Palestinian State}

Despite the nature of the changes in Israeli policy in the context of the peace process, the goals remain the same: protecting Israel's existence and the security of its citizens, which can be summarized in ensuring Israel's security and survival. Israeli governments have focused on the benefits that can be gained from achieving peace between Palestinians and Israelis. In ensuring Israeli security, we can say that three fundamental factors are the cornerstone of Israeli politics. 


\subsection{Israeli Strategic Goals}

Since the declaration of the establishment of Israel on May 15, 1948, Israel has sought to establish the Jewish state as the starting point for controlling more land and evoking Jews from all over the world. The Israeli religious and secular parties were a clear example of this policy in ensuring Israel's strategic objectives. The principles of the Israeli strategy for structural changes beginning with the October 1973 war, and it failed to employ the principle of war and the war in Lebanon in 1982 which was called the Peace of Galilee War, which proved that the wars of choice, as the Israeli Prime Minister "Menachem Begin" named it at this time, it may entail a political repercussions threatening the security of Israel, and may increase its regional isolation, with mounting the international pressure to end it, if it is not determined by the objectives of the political level and to provide a sufficient justification to start it (Efraim, 2008).

Israel has limited the options to the de facto status quo, which has negative repercussions on Israel, the increase in the number of Palestinians in Israel, and the threat of the demographic balance of the Jewish state. The most prominent factor in the structural change in the Israeli strategy was the 1991 Gulf War, Security and strategic depth following the infiltration of Israeli Scud missiles into Israeli airspace, prompting Yitzhak Rabin to assert that geography is no longer a security factor with the spread of short- and medium-range missiles in the Arab countries (Dore, 2003).

The Israeli strategy has undergone many changes as a result of the changing nature of the threats, with the diminishing probability of armed conflicts with neighboring countries, in maintaining the strategic constants, namely, Israel's survival and its military superiority as a de facto state of neighboring countries, its monopoly on acquiring nuclear weapons and the war of war. This avoids the Israeli internal front the consequences of military confrontations, and long-term wars of attrition that test the state's ability to afford material and human costs that it cannot afford in the absence of strategic depth.

\subsection{Israeli National Security}

Israeli National Security is established on three main principles: risk alert, deter enemy from attack and resolve the battle quickly if a war breaks out. The Israeli security strategy is central to Israeli security thought, but the military factor is one of the most decisive factors in the Arab-Israeli conflict. The Israeli leaders, after the June 1967 war, frequently referred to as the safe border, and the leaders sought to preserve the territories which they occupied it in 1967. Golda Meir, the former Israeli prime minister, said that if Arab leaders agreed to sign a full peace agreement with Israel, all the territories it occupied in 1967 would not be returned because we want a secure border. Israel's secure borders are considered to be changing and expanding concepts in line with the requirements of Israeli security (Al-Masri. 2008). The importance of secure borders lies in the fact that they provide for the defense of the State without resorting to pre-emptive warfare, so the idea of safe borders has allowed the abandonment of the strategy of the first offensive strike. (Mansour and Nahas, 2009)

Israel's idea has relied upon many security advantages which has gained from controlling the Golan Heights and the West Bank. Israel's withdrawal from the West Bank is an Israeli loss and a strategic retreat, because the West Bank is characterized by mountainous mountains overlooking the coastal area. In addition to that the area will be in the Arab line of fire and artillery, and if the area falls under Arab artillery will divide the coast to two parts because the distance between the mountains of the West Bank and the coast is approximately $15 \mathrm{~km}$. This gives rise to Israel's need to carry out a preemptive attack in the event of the concentration of Arab hostile crowds on the Israeli border or any threat to Israeli national security (Mahmoud, 2007).

The Israeli thought depends on preemptive strikes and the transfer of the battle to the enemy's territory. This includes flexibility and dynamism that makes it more suited to the strategic positions that Israel may face (Mansour \& Nahas, 2009). After the 1967 war, it managed to acquire the necessary strategic depth, the topographic barrier in the West Bank's mountains, and therefore Israel has removed its population and vital installations from any sudden ground attack (Al-Emla, 1990).

Most Israeli army commanders believe that recognizing a Palestinian state would entail several risks from a security point of view, because the establishment of a Palestinian state would reduce Israel's strategic depth (Shiva, 1999). The vision was that the army would control the main roads connecting the Jordan River in the West Bank. In order to provide sufficient time to mobilize Israeli forces in the event of any possible Arab attack, the Israeli leadership in the 1990s worked to redesign and structure the Israeli army and build its components. This strategy focused on the existence of a smaller, more advanced army. The main goals of the expanding Zionist project remain stable and unchanging (Sha'ban, 1993). Israel sees that removing arms, security cooperation and controlling land, air and sea ports are necessary steps needed before peace is achieved. Without these steps, the conflict will find no solution and conflict management will revolve around gaining more time 
and settling matters depending on the status quo (Hussein, 2015).

\subsection{Settlement}

The Zionist project in Palestine is based on immigration, expropriation and settlement of the Palestinian territories. After the occupation of Jerusalem, the West Bank and Gaza Strip, successive Israeli governments and military forces have worked to build settlements in areas of security and military importance. They have also worked to expand them, seize land and increase the number of settlers.

Israel has occupied more than $85 \%$ of the historical area of Palestine, which is about $27000 \mathrm{~km} \mathrm{2,} \mathrm{which} \mathrm{is} \mathrm{rich}$ in natural resources. Israel prevents Palestinians from benefiting from these resources. The number of settlement sites and military bases in Israel in the beginning of 2016 in the West Bank is 413 sites, including 150 settlements and 119 random settlement outposts and 144 sites and military base. And Israel has built the apartheid wall, which isolated more than 12 percent of the West Bank with the goal of severing the West Bank and preventing the establishment of a Palestinian unit between its areas. Israel has isolated these areas from each other through the apartheid wall (Wafa, 2016).

In the West Bank and Jerusalem, the number of settlers and settlements has increased by 600 percent since the signing of the Oslo Accords in 1993. The number of settlers in the West Bank and Jerusalem at the end of 2016 is more than 765,000 Jewish settlers in various locations. These locations were demolished by the occupation forces in the West Bank from the occupation of 6000 residential and non-residential facilities until mid-2016. The Israeli occupation intensifies through the intensification of settlement, and construction in East Jerusalem will continue to be an essential part of the eternal capital of Israel. The city of Jerusalem has, ever since its occupation in 1967, been subjected to the process of subversion and deportation of Palestinians, including the demolition of houses, which amounted to 2599 houses and the seizure of others in a settlers' neighborhood in Eastern Jerusalem (Wafa, 2016). Since Netanyahu took over as prime minister in March 2009, a government that included parties from far-right Israel that has been turned into a settler government, the pace of settlement has grown so unprecedentedly that it can be described as alienating the Palestinian people and their lands. The right-wing government headed by Netanyahu has worked to blur the Arab character in Jerusalem by intensifying Jewish settlement in the city and changing the names of streets and neighborhoods with the aim of destroying them.

The settlement issue was discussed at the Camp David talks in 2000. The Israeli proposals included the annexation of these settlements to three settlement blocks inhabited by approximately 250,000 settlers who would retain Israeli citizenship, while approximately 100,000 Palestinians residing in those areas would be denied their minimum political rights when they are included in the Israeli state (Tamari \& Hamami, 2001). These facts which were imposed by Israel on the ground represented an obstacle to reaching political solutions between the Palestinian and the Israeli side. Israel raised the idea of adjustment of the border in the exchange of land. This issue of adjustment of borders is another form of Israeli dictations, so that all foreign and security affairs of the self-government will be placed under the Israeli responsibility, in addition to the process of population exchange without evacuating the settlements (Sha'ban, 2004), these proposals were dictated by Israeli policy based on Israel's security requirements.

The issue of keeping the settlements gained the approval of all the various political ideologies in Israel. The Israeli settler-policy aims at making the settlement blocks and settlements in the Jordan valley as a part of Israeli land. Israel, through its own security concept of settlements and including the three settlement blocks to its territory, to preserve the Jewish nature of the country. This can be done through the removal of Palestinian villages from their position on the Green Line to the Palestinian state borders as well as Israel's retention of control of the West Bank Heights and the establishment of early warning stations. These steps came to achieve the constants of the Israeli security theory of safe borders and strategic depth. In the West Bank, Israel is not serious about achieving a political settlement that meets the minimum demands of the Palestinian leadership. Israel has worked under the cover of settlement and negotiations to impose facts on the ground through settlement in the West Bank, especially East Jerusalem.

\section{The Political and Public Israeli Opinion of the Palestinian State}

The Israeli views regarding their attitudes of the Palestinian State varies, in addition to Israeli public opinion, all views do not rise to an independent and sovereign Palestinian State, and therefore this suggested state must meet Israel's national security and political interests. Political parties along with religious parties, Israeli movements and organizations play an important role in the process of making internal and external political state, and the position of the Palestinian State. 


\subsection{The Party System in Israel}

Security concern remains in control of the program of the political parties in Israel with the approaching of the electoral process; security principles have been repeatedly mentioned in the election. The majority of Israeli parties whether leftist, rightist or religious, which shape the security-political policy in Israel, refuse to give up some Palestinian areas under the pretext of securing Israeli borders. Israel considers these areas, particularly Jordanian River, border regions, mountainous and fertile regions, in terms of strategic importance. This security pretext is an attempt of Israel to cling to the land.

Differentiation between Israeli political parties began since the 1990s. This differentiation was based on the ideological position which is based upon foreign affairs and security in addition to the party's opinions on peace agreements, settlements, Jerusalem, refugees and the Palestinian State (Newberg, 1991). However, Israeli parties stand on the conviction of having a Jewish state, and there is a broad consensus among political parties in Israel that rejects the establishment of a Palestinian state within the territories controlled by Israel (Ya'er, 2002). These parties are divided into three political camps: right-wing and left-wing and religious.

\subsubsection{Right-wing Parties}

A number of political parties fall under the Right camp of Israel including the "Likud", which was formed through the time as a result of alliances and merges between parties (Madi, 1999)."National Union" is a very extremist party which was found in 1999 from the merge of three smaller parties: the "Moledit Weherot", "Tacoma", and "Israel Baituna" party which joined in 2000 (Khalifa, 2004). This camp also has "Yaood" party, which was founded in February 1994 by a group who defected from the "Tasawamat" party, in addition to "Htehiya" which is an extremist nationalist party (Al-Jabbouri, 2009).

The vision of Right-wing parties, especially the "Likud" party, aims to give the Israelis the right to own land in the occupied territories. This project is based on three principles (Hajjaj, 2012):

1. Arabs in the West Bank and Gaza Strip are a minority and have the right to enjoy autonomy within the State of Israel.

2. The Intended autonomy is administrative in nature and relates to religious, cultural and Social Affairs.

3. The autonomy includes people not land which means that Israel's control over land and building settlements continues. The project cannot lead to a Palestinian State.

The "Likud" party supports settlement projects in the West Bank and Gaza strip, and it opposes withdrawal from the territories occupied by Israel in 1967. Several withdrawals occurred during the time of this party one of which was when "Camp David" agreement was signed under Prime Minister "Menachem Begin" which ended in Israel's withdrawal from Sina'. When Sharon, who had led the "Likud" party and founded "Kadima" party, separated from the party in 2005, a unilateral withdrawal from the Gaza strip took place.

The "Likud" party opposed the Oslo agreement and did not recognize the Israeli-Palestinian negotiations. As a result, it does not support a compromise under which the land is waived nor does it support the creation of an independent Palestinian state. The party's platform is based on allowing limited autonomy in the occupied Palestinian territories and improving the economic life of Palestinians. "Netanyahu's" plan in 2009 considered Israel as a Jewish State and Jerusalem as the capital of Israel. The plan included the construction of close to 80 percent of the West Bank and delaying negotiations on the city of Jerusalem and the refugees (Shalhat, 2009).

The policy of the Likud party and the right-wing parties oppose the creation of a Palestinian state. It doesn't allow Palestinians to control their borders and their field; it prevents them from holding military agreements with other countries and it does not allow them to be armed or to control water resources. Palestinian refugees are also deprived of their right to return to the 1967 lands. In addition, this policy stands against the division of Jerusalem and calls for a united Jerusalem as the capital of Israel.

\subsubsection{Left-Wing Parties}

Israeli parties which fall under the camp of the left party include: the "Labor" party and "Meretz" bloc which is a merger of the "Mbam" and "Shinui" parties, and two small groups "Shaher" movement and "The Democratic option" party in addition to the "one people" party which is a political expression of "Histadrut". Left parties reject the establishment of a Palestinian State in the occupied territories. Golda Meir, the party's leader, pointed up her repudiation of having a Palestinian state within the occupied territories, and she stressed that from Iraq to the Mediterranean it is not possible for two independent states, a Jewish and an Arab state, to exist (Khalifa, 2004).

Both of "Yitzhak Rabin" and "Abba Eban" saw that the idea of having a Palestinian State is not a realistic one, 
and the return of Jordanian sovereignty over the West Bank is the only possible choice. "Moshe Dayan" suggested, in 1968, the establishment of a Palestinian autonomous administration under Israeli occupation, and in 1973, he showed intense opposition to the idea of a Palestinian state. In 1971, "Yigal Allon" suggested a Confederation between Jordan and Israel taking in Palestinians. In 1972, "Shimon Peres" suggested having a federal Union between Israel and the Arabic countries in the West Bank, and establishing a federal government to handle finance and security. He demonstrated that dividing the land will not bring peace. During this epoch, political parties, especially the "Labour" and "Likud", portrayed the Jordanian option as the key to peace. However, a number of changes and developments overturned the Israeli view and brought into attention the two-states solution. These changes include: "The stone Intifada" in 1987, the Palestinian National Council in 1988, and the Declaration of independence. They were followed by the legal and administrative disengagement between Jordan and the West bank which resulted in the nullification of the Jordanian option (Khalifa, 2004).

The policy of the "Labor" party rejected the withdrawal from the occupied territories of 1967 . The party is supportive of the establishment of two states living side by side in peace where the settlement blocs of high Jewish density remain under the Israeli authority. It also considers Jerusalem, with all its Jewish neighborhoods, the eternal capital of Israel. In addition, the party seeks to gain international recognition of Jerusalem as the capital of Israel, and it emphasizes that a political settlement between the two sides should ensure the Palestinian Authority's intention to maintain calm and security in all its territories including the Gaza strip. The party has opposed the return of refugees to the 1948 lands since the Palestinian Authority is responsible for accommodating every Palestinian within its territories.

\subsubsection{Religious Groups}

Religious groups in Israel are divided into two parts: the religious Zionists who are referred to as "Htsionim" in Hebrew, and religious puritans who are called "haridim" and they both belong to the Orthodox current in Judaism. The first part represents "The National Religious Party (NRP)" and "wemimad" while the other part represents "Agudat Israel", " Degel Hatorah" and "defiant" in one block called " YEHOTUT HETURAORA", in addition to "Chas" party. (Zughaib, 2005)

Religious groups have their own view regarding the compromise. It is based on their religious doctrine which is known of the intolerance that originates from the legend of the holy book; the changes in the surrounding circumstances do not change it. As a result, religious groups believe in the Jews' right to settle in the land of Israel. This right is given priority over any political, strategic or economical consideration. In addition, religious groups reject the idea of giving up the occupied territories after 1967, and they oppose the creation of a Palestinian State. "NRP" party refuses to cede the occupied territories deeming them as Israeli territory, and demands the establishment of Israeli sovereignty over the West Bank and Gaza Strip. "aguadt Israel" party calls the Israeli government for encouraging Arabs to leave by offering them material inducements (Madi, 1999).

It could be said that there is consensus among Israeli political parties, right-wing or left-wing, and religious groups about the Palestinian State because there are fixed principles which Israeli parties cannot exceed. Although the statements and projects vary but the core principles are invariable. The following are foundations and considerations upon which the Israeli parties rely:

1. The failure of a sovereign Palestinian State.

2. Jerusalem is not a negotiable subject, and it is Israel's eternal capital.

3. The return of refugees to their towns and villages is not possible.

4. Israel will keep the settlement blocs in the West Bank

\section{The Israeli Public Opinion on the Palestinian State}

In March 2007, the Institute of National Security Studies held a study on the Palestinian State. The study proved that $63 \%$ of the adult population in Israel is in favor of a two-State solution for two people. However, as long as the Palestinian leadership refuses to recognize the State of Israel as a Jewish State, there will be no solution to the conflict, and the Jewish people should not submit a waiver unless a correspondent Palestinian declaration acknowledge Israel as the national State of the Jewish people (Ghanem et al., 2011).

An Israeli public opinion poll, carried out by Institute of National Security Studies at the University of Tel Aviv in 2009, showed the willingness of the Israeli public to approve a permanent settlement on the establishment of a Palestinian State in the West Bank and Gaza Strip has increased steadily over the past two decades. The proportion of supporters increased from $21 \%$ in 1987 to $61 \%$ in 2006 , and then decreased to $55 \%$ in 2007 , and then to $52 \%$ in 2009 . However, support for the two-State solution is still high; $63 \%$ of the Israeli public approve 
it, and in 2009 the proportion amounted to $64 \%$. The interpretation of this divergence is that the term "Palestinian State" still terrifies the Israeli Public, but "the two-State solution for two peoples" was acceptable to the majority of the Israeli public as the only realistic solution to the conflict (Shalhat, 2009). Netanyahu's acceptance of the two-State solution reflects the consistent with the dominant opinion among the Israeli public.

Yehuda Ben-Meir, researcher at the Institute of national security studies, said that some press reports affirm that Palestinians are opposed to the "Two-states for two peoples" wording, and are supporting the "Two states" only term. The topic here is not a discussion of wording yet it revolves around the core of the conflict. This topic is here that Israel cannot compromise or discuss under any circumstances as it relates to its real existence (Ghanem et al., 2011).

The journalist "Raviv Drucker" sees that the requirement of recognition of Israel as a Jewish State saw the light for the first time during the reign of Israeli Prime Minister Ariel Sharon 2001-2005. He adds that Israel's leaders should consider putting up a precondition for negotiations. Professor "Urammital", Middle Eastern Studies Professor at Ben Gurion University, believes that "Netanyahu's tent, which is that the recognition of Israel by the Palestinian State as the national state of Jewish people is the cornerstone of peace, and reveals the ideological basis for the head of Government. Most Israelis believe that the Arab general opposition of the recognition of this request questions the existence of the State of Israel, and reflects an initial opposition to the recognition of their sovereignty. The journalist Gideon Aishet Israel's political leaders adopt a requirement for recognition of Israel as national State of the Jewish people, hence the great importance of this demand lie in front of the Israeli public.

Professor Yehuda shanhav, a sociologist at Tel Aviv University, called for adaptation of the one-State option believing that a two-State solution is not viable due to the Israeli policies, and that the best solution to the Palestinian issue is to ensure the rights of citizenship in a democratic State for all its citizens. In addition, the two-states solution in light of the political condition in the region in not viable as it puts Palestinians in Israel in danger. (Shenhav, 2013)

The Palestinian Center for political and survey research and the Israeli democracy Institute held a public opinion poll in June 2016 which showed that nearly half of Israelis support a two-state solution because both of the sides, Palestinian and Israeli, don't trust each other and have diverse views of a settlement. Israelis see that the intentions of the Palestinian side are a threat to them. The survey demonstrated that nearly $58 \%$ of Israelis support a two-State solution, and that nearly $46 \%$ of them support a peace agreement based on a single package, unarmed Palestinian State and an Israeli withdrawal from 1967 borders. It also showed that nearly 68\% of Israelis agree to a mutual recognition and to live within two States for two peoples and to fight against terrorism.

Another Israeli public opinion poll, carried out in December 2016 by the Palestinian Center for political and survey research and Tammy Shtaimz peace research center in Tel Aviv, found that nearly 55\% of Israelis support a two-State solution and this support was based on a settlement between Palestinians and Israelis which should end in the creation of unarmed Palestinian state. Regarding the annexation of the west bank to Israel without giving Palestinians full citizenship rights, nearly $46 \%$ Jewish settlers support the idea of annexation while $45 \%$ oppose it (Pulse of Palestinian and Israeli Public Opinion, 2017). It's noticeable that the majority of Israelis support the principle of two-State solution within a comprehensive and detailed package to implement this solution. However, Israeli fears and the absence of trust prevent any peace agreement between the Palestinian and Israeli sides.

The Israeli notion of a Palestinian State is not to recognize it which enhances the Israeli actions of expanding settlements, building the apartheid wall, alteration of Jerusalem, in addition to the alignment of the Israeli society towards extremist Rightist party. All those preclude the creation of an independent and sovereign Palestinian State.

\section{Conclusion}

The study illustrated the Israeli formal and informal position of the Palestinian state. It also discussed the Israeli political thought and strategy on the Palestinian State which includes the preservation of national security and settlements in the 1967 occupied Palestinian territories. This is in spite of all international and regional calls to withdraw from the 1967 borders. Israel aims through this to prevent any political plan to establish an independent Palestinian state.

The study also dealt with the attitude of the Israeli political parties; it found that all the Political groups in Israel stand against the creation of a Palestinian state. The effort they make to prevent this can be seen through the different projects which the parties put forward every once in a while. The goal of these projects always revolves 
around rejecting the creation of a Palestinian state, shutting down negotiations about Jerusalem, opposing the return of Palestinian refugees, and focusing on not to evacuate settlements in the West Bank.

Furthermore, the study pointed out the Political leadership and public opinion in Israel regarding the Palestinian State. The Israeli thoughts and view vary but they don't amount to the creation of a Palestinian state. Such State should follow political and security demands of Israel. Israel has sought to settlement expansion in the West Bank and Jerusalem and the Jordan Valley in addition to the construction of the apartheid wall aiming to prevent the rise of a geographically contiguous Palestinian state.

The results of this study are as follow:

1. Israel creates obstacles to the establishment of an independent and sovereign Palestinian State.

2. The Israeli political ideology is based on the legends of the Torah and the Talmud where the land is considered the Promised land of the ancestors and thus should not be abandoned.

3. All political parties in Israel agree on not to cede the territories occupied by Israel since they guarantee it a secure border and provide strategic depth.

Israel gives the world the impression of being a peace seeker while its actions show the opposite.

The remaining question is: will Trump's government be able to revive the peace making process between Palestinians and Israelis to achieve a two-States solution and establish a Palestinian State on the 1967 borders after the suspension of negotiations?

\section{References}

Al-Emla, M. (1990). Arab National Security and its Theory of Application in the Face of Israeli Security. Amman: Dar Al-Jalil for Publishing.

Al-Jabouri, A. (2009). The Elements Affecting Israeli Decision Making. Damascus: Damascus Center for Civil Rights and Academic Studies.

Al-Masri, M. (2008). The Israeli Theory of Security. Ramallah: The Palestinian Center for Research and Strategic Studies.

Dore, G. (2003). Defensible Borders for Israel. Jerusalem Center for Public Affairs. Retrieved from http://jcpa.org/program/defensible-borders-for-israel/

Efraim, I. (2008). Israel's National Security Issues and Challenges since the Yom Kippur War. New York: Rutledge.

Ghanem et al. (2011). The Meaning of a Jewish State. Ramallah: The Palestinian Center for Israeli Studies (MADAR). Retrieved from https://www.madarcenter.org/en/

Hajjaj, T. M. The Positions of the Different Israeli Parties on the Palestinian. Issue. Urban Dialogue. Retrieved from http://felesteen.ps/details/new /76403/\%D8\%B9\%D8\%AF\%D8\%AF

Hussein, K. (2015). Determinants of the Israeli National Security Policy in the Light of the Arab Revolutions. The Arab Democratic Center. Retrieved from Http://democraticac.de/wordpress/?p=219

Khalifa, A. (2004). Political Parties in Israel. Beirut: The Palestinian Studies Institute.

Madi, A. (1999). Religion and Politics in Israel: A Study of Religious Parties in Israel. Cairo: Madbouli Bookshop.

Mahmoud, K. (2007). Israeli Security: Reality and Future. Beirut: Al-Zaytouna Center for Studies.

Mahmoud, K. (2011). Two-thirds of the Jews are not with the Establishment of a Palestinian State. What is the solution? Palestine Newspaper,

Mansour, J., \& Nahas, F. (2009). The Israeli Military Institution: History, Reality, Strategies and Formations. Ramallah: The Palestinian center for Israeli Studies.

Morsi, M. (2016). The Jewishness of the State in Contemporary Israeli Political Thought and its Implications for the Palestinian Cause. The Arab Democratic Center. Retrieved from http://democraticac.de/?p=69

Newberg, B. (1991). Parties in Israel. Rimat Aviv: Open University.

Palestinian Center for Policy and Survey Research. (2016). Pulse of Palestinian and Israeli Public Opinion. Retrieved from http://pcpsr.org/en/node/663 .

Palestinian Center for Policy and Survey Research. (2017). Pulse of Palestinian and Israeli Public Opinion. 
Retrieved from Http://pcpsr.org/en/node/679

Sha'ban, A. (1993). Israel's political Strategies in 2000. Cairo: Sinai Publication.

Sha'ban, K. (2004). The Effects of Intifada on Israeli Political Ideology. Derasat Baheth Journal.

Shalhat, A. (2009). Palestine in Netanyahu's Agenda. Israeli Cases. Ramallah: The Palestinian Center for Israeli Studies (MADAR). https://doi.org/978-9950-330-50-4

Sheiv, Z. (1999). An Israeli Perspective: Pre-Conditions for the establishment of a Palestinian State. Samed Al-Eksady Journal. (118).

Shenhav, Y. (2013). The Two-State Solution is Inapplicable and Must be Forgotten. Retrieved from Http://www.alwatanvoice.com/arabic/news/2013/05/02/388958.html

Tamari, S., \& Hamami, R. (2001). Al-Aqsa Intifada: The Background and Diagnosis. The Palestinian Studies Journal, 14, 45-46.

The Palestinian News and Information Agency (Wafa). (2016). State of Settlers. Retrieved from Http://www.wafa.ps/en_page.aspx?id=7jxCTsa697501703580a7jxCT

The Palestinian News and Information Agency (Wafa). (2016). Statistics: Israel controls More Than 85 percent of historic Palestine after the Nakba. Retrieved from Http://www.wafa.ps/en_page.aspx?id=u52Dcza692213763912au52Dcz

Ya'er, F. (2002). Oslo and the Israeli Public Opinion: Is it a Disappointment? Tel-Aviv: Tami Shtaints for Peace Studies, University of Tel-Aviv.

Zughaib, Y. (2005). Is the Zionist Community Ready for A Settlement? A Researcher's Studies Journal, (9).

\section{Copyrights}

Copyright for this article is retained by the author(s), with first publication rights granted to the journal.

This is an open-access article distributed under the terms and conditions of the Creative Commons Attribution license (http://creativecommons.org/licenses/by/4.0/). 